\title{
KONSERVASI LINGKUNGAN DALAM PERSPEKTIF USHÛL AL-FIQH
}

\author{
Mudhofir Abdullah \\ STAIN Surakarta \\ Email: mudhofir@yahoo.com
}

\section{Abstract}

Environmental crisis is not only a matter of ecological damage, but also a matter of moral and spiritual crisis. Some have realized that to solve these crisis, they should take a comprehensive way both ecological and spiritual as well. Syari'ah as perennial source of Islamic tenets should be explored into practical guide for Muslim around the world. Nevertheless, Syariah couldn't be explored effectively without specific tool like ushûl al-fiqh. This paper will deal with the role of ushûl al-fiqh in the deconstruction and reconstruction of Syari'ah law for environmental conservation. Furthermore, I name it eco-ushûl al-fiqh as one of argument for environmental conservations on Syariah perspective.

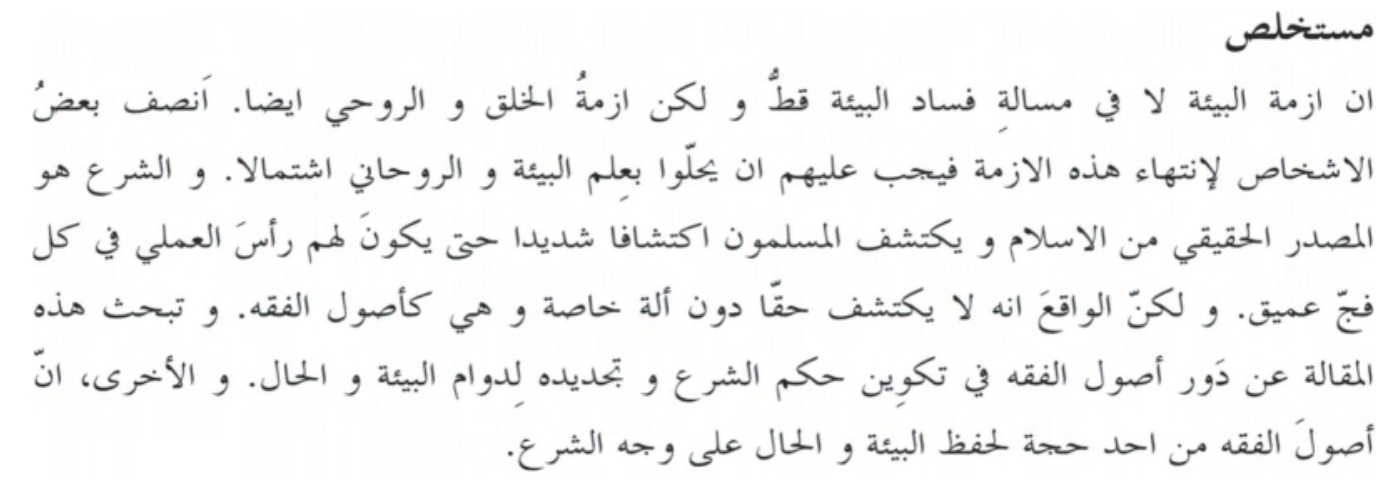

Keywords: Konservasi, Lingkungan, Eko-ushûl al-fiqh, Mashlahat, Syari’ah

\section{A. Pendahuluan}

Argumen tentang prinsip konservasi lingkungan dalam perspektif eko-ushûl alfiqh dewasa ini telah menjadi isu aktual di tengah-tengah ancaman krisis lingkungan global. Banyak penulis yang berusaha menjadikan ushûl al-fiqh sebagai tool untuk 
mengeksplorasi analisis-analisis Syari'ah terkait dengan konservasi lingkungan. Ini dilakukan karena krisis lingkungan telah banyak disinggung dan diisyaratkan di dalam al-Qur'an serta menjadi keperihatinan global, namun elaborasinya belum maksimal dipaparkan dalam analisis ilmiah. Pesan-pesan Syari'ah seperti belum terpapar secara jelas terkait konservasi lingkungan, sehingga terasa dibutuhkan penjelasan-penjelasan dari banyak ahli agar mampu memberi kapasitas umat Islam dalam berkontribusi di bidang penanggulangan krisis lingkungan global melalui pintu dekonstruksi ushûl al-fiqh. Dalam konteks makalah ini, saya akan memakai istilah eko-ushûl al-fiqh, sebuah istilah yang ketepatannya masih bisa diperdebatkan.

Komponen-komponen lingkungan di dalam Syari'ah, tentu saja, pengertiannya bersifat generik (مجمال). Pemaknaan baru dan rinciannya yang terkait dengan konservasi lingkungan perlu dilakukan agar lebih operasional. Hal ini dilakukan dengan menggali makna konservasi lingkungan melalui pemahaman kembali karya tafsir dan fikih secara tematik (mawdhû̀̂̀) dengan unit analisisnya yakni metodologi yurisprudensial atau ushûl al-fiqh (أصول الفقه). Inilah yang disebut sebagai pendekatan eko-ushûl al-fiqh untuk konservasi lingkungan. Karena itu, prinsip-prinsip mashlahah dan al-maqâshid al-syarîah dengan seluruh percabangannya akan dibahas dalam kerangka analisis eko-ushûl al-fiqh tersebut.

\section{B. Paradigma Eko-Ushûl al-Fiqh}

Eko-ushûl al-fiqh merupakan gabungan dari kata "eko" dan "ushûl al-fiqh." Kata "eko" dalam tradisi pemikiran ecothinkers menunjuk pada ekologi yang berarti ilmu tentang hubungan antara tanaman dan binatang dengan lingkungan fisik serta biologis yang mendukungnya. ${ }^{1}$ Definisi lain ekologi adalah ilmu tentang hubungan timbal balik antara makhluk hidup dengan lingkungan hidupnya. ${ }^{2}$ Sementara ushûl al-fiqh berarti ilmu tentang prinsip-prinsip (qawầid) yang merupakan metodologi (manâhij) untuk menggali (istimbâth) hukum-hukum praktis dari dalil-dalilnya yang rinci. ${ }^{3}$ Dengan gabungan makna tersebut, eko-ushûl al-fiqh dapat diartikan sebagai studi tentang hubungan makhluk hidup dengan lingkungan hidupnya dari perspektif ilmu ushûl al-fiqh. Atau suatu kajian tentang isu-isu lingkungan dari titik tilik filsafat hukum Islam.

1 Microsoft Encarta Encyclopaedi CD-ROM, 2002, s. v. "Ecology"

2 Otto Soemarwoto, Ekologi, Lingkungan Hidup, dan Pembangunan (Jakarta: Penerbit Djambatan, edisi ke-8, 2004), hal. 22

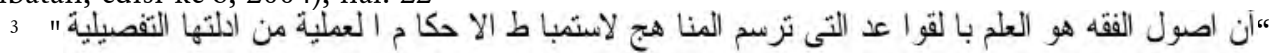
Lihat definisi ini pada Muhammad Abu Zahrah, Ushk】 al-Fiqh (Kairo: Dr al-Fikr,t.thal.), hal. 7 
Perlu dijelaskan bahwa, ushûl al-fiqh dalam tradisi keilmuan Islam merupakan prinsip utama yang digunakan para ulama untuk memahami maksud-maksud alQur'an dan Hadits. Kandungan al-Qur'an dan Hadits yang tidak seluruhnya bermakna tegas dan jelas mendorong ulama untuk membuat metodologi sehingga terhindar dari cara-cara arbitrer (arbitrary) di dalam memahami nushûsh (teks-teks) al-Qur'an. ${ }^{4}$ Imam al-Syâfî̀̂, misalnya, menulis kitab al-Risâlah-yang merupakan karya ushûl pertama dalam sejarah Islam-dimaksudkan untuk mengatasi problem istimbâth hukum secara sewenang-wenang yang marak dilakukan pada masanya. ${ }^{5}$ Dalam latar dan pengertian inilah, eko-ushûl al-fiqh digunakan untuk meningkatkan kapasitas penggalian hukum atau etika Islam yang fokus pada masalah konservasi lingkungan.

Dengan mengarahkan perangkat metodologi semacam ini ke analisis ekologi, maka bukan saja terhindar dari kekeliruan atau bias dalam kesimpulankesimpulannya, tetapi juga memungkinkan prinsip-prinsip ushûl al-fiqh menghasilkan kesimpulan-kesimpulan ekologis untuk menopang argumen konservasi lingkungan yang kemudian saya sebut sebagai eko-ushûl al-fiqh. Cara semacam ini juga dilakukan sejumlah ulama ketika mereka berbicara tentang Islam dan isu-isu lingkungan seperti Yusuf Qaradhawi, Musthafa Abu-Sway, Mawil Y. Izz Deen, dan lain-lain. Bahkan karya klasik ushûl al-fiqh seperti Mustashfâ, ${ }^{6}$ al-Muwâfaqât, ${ }^{7}$ dan lain-lainnya telah menyebut istilah mashlahat dan al-dharûriyyât al-khams yang berintikan perlindungan pada lima komponen lingkungan penting, yakni: memelihara agama, jiwa, keturunan, properti, dan akal. Dengan menganalisis teori-teori mashlahat dan al-maqâshid al-syar'iyyah guna melindungi secara permanen al-dharûriyyât al-khams pada kerangka eko-ushûl al-fiqh, maka konsep-konsep utama konservasi lingkungan memperoleh titik fokusnya.

Paradigma eko-ushûl al-fiqh, karena itu, menyuguhkan sedikitnya tiga prinsip utama konservasi lingkungan. Pertama, meningkatkan kapasitas ushûl al-fiqh terutama yang terkait dan mendukung konsep konservasi lingkungan meski harus mengkritik prinsip-

4 Bandingkan dengan al-Syawknî, Irsyd al-Fuhkkl il Tạhqîq 'Ilm al-Ushkl, hal. 44. Dalam kalimat " القانون الذى يلتزمه الفقيه ليعتصم به من الخطأ في الا ستمباط" (suatu pedoman yang membantu seorang ulama terhindar dari kekeliruan mengambil kesimpulan hukum). Periksa kembali Muhammad Abu Zahrah, Ushkl al-Fiqh, hal. 10.

5 Lihat Muna Abu al-Fadhl, Nahwa Manhajiyyt al-Ta'[nul ma’a Mashdir al-Tanzhîr, hal. 272-278.

286-287

Abu Hamid al-Ghazali, Mustashfmin 'Ilm al-Ushkl(Bagdad: Mutsann_ 1970), Jilid I, hal. al-Sythibî , al-Muwfaqt fî Ushkl al-Syari’ah, Jilid II, hal. 3, 16, 17. 
prinsip yang sudah ada yang tidak relevan lagi dan membuat prinsip-prinsip baru berdasarkan argumen-argumen yang aktual. Kedua, mengeksplorasi prinsip mashlahat dan al-maqâshid al-syar'iyyah untuk konservasi lingkungan, dan ketiga, memperluas cakupan mashlahat yang bukan hanya menurut kerangka al-Ghazali dan al-Syâthibî, yakni: mashlahat yang telah disebutkan oleh Syari'ah (al-Qur'an dan Hadits), ${ }^{8}$ tetapi juga mashlahat apa saja yang memiliki dimensi kebaikan dan kemanfaatan ${ }^{9}$ seperti: masalah teknologi ramah lingkungan, mencegah pencemaran, mencegah produksi ekonomi yang mengabaikan masalah lingkungan, dan lain sebagainya.

Jadi, sebagaimana ekoteologi dan ekosofi yang mengkaji konservasi lingkungan dari titik tilik teologi dan filsafat serta tasawuf, maka eko-ushûl al-fiqh berusaha menggunakan prinsip-prinsip hukum Islam untuk menemukan konsep-konsep utama konservasi lingkungan. Dari argumen tersebut, dapat dikemukakan bahwa jika produk-produk fikih di masa lalu merupakan hasil dari ijtihâd sesuai dengan ruang dan waktu yang boleh jadi sudah tidak relevan lagi dengan jaman ini, maka ushûl al-fiqh sebagai suatu prinsip hukum Islam masih tetap relevan digunakan karena bersifat philosophia perennis, yang dalam studi ini digunakan untuk mengeluarkan prinsip-prinsip konservasi lingkungan. Sebelum masuk ke bahasan konservasi lingkungan dalam perspektif eko-ushûl al-fiqh, akan dibahas terlebih dahulu aspek-aspek lingkungan dalam Syari’ah.

\section{Konservasi Lingkungan dalam Perspektif al-Maqâshid al- Syar'iyyah}

Perspektif al-maqâshid al-syar’iyyah dalam wacana konservasi lingkungan secara generik telah disinggung oleh Musthafa Abu-Sway ${ }^{10}$ dan Yusuf Qaradhawi. ${ }^{11}$

8 al-Sythibî berbicara mashlahat hanya dalam batasan Syari'ah dan tidak dalam pandangan manusia. al-Sythibî, misalnya, mengatakan bahwa tujuan Syari’at adalah untuk membebaskan para mukallaf dari belenggu hawa nafsunya hingga mereka bisa menjadi hamba-hamba Allahal. Pandangan al-Sythibî ini, tentu saja, menafikan pertimbangan pribadi atau individual sebagai unsur dalam pertimbangan mashlahat. Lihat al-Sythibî, al-Muwfaqt, Jilid II, hal. 16, terutama dalam المسأ لة الخا مسة

9 al-Thkfî, justru berpendapat bahwa akal secara mandiri bisa menentukan mashlahat dan mafsadat, terutama dalam lapangan mu'malat dan 'dat. Piramida pemikiran al-Thkfî tentu saja berbeda dengan al-Sythibî dan lebih luas. Lihat Najmuddin al-Tkffi, Syarh al-Arba+ $\not$, dimuat dalam lampiran Mushthaf Zayd, al-Mashlahat fi al-Tasyr' al-Islmî wa Najmuddîn al-Thkfî (Kairo: Dr al-Fikr al'Arabi, 1954), hal. 18.

10 Musthafa Abu-Sway, Towards an Islamic Jurisprudence of the Environment: Fiqh al-Bî̀ah fial-Islm dalam http://homepages.iol.ie/ afifi/Articles/environment.htm

11 Yusuf Qaradhawi, Islam Agama Ramah Lingkungan..., hal. 59-73 
Mengikuti analisis kedua tokoh ini, para penulis dan pemerhati lingkungan dewasa ini seperti: M. Fadhlun Khalid, Ibrahim Ozdemir, dan lain-lainnya belakangan memperkaya perspektif-perspektif mashlahah sebagai prinsip Islam tentang konservasi lingkungan. ${ }^{12}$ Namun harus disebutkan bahwa Yusuf Qaradhawi dan Musthafa Abu-Sway juga meminjam analisis Imam Ghazali, al-Syâthibî, al-Syawkânî, dan lain-lainnya terutama teori-teori mashlahat dan al-maqâshid al-syar'iyyah untuk memperkokoh argumen-argumen mereka tentang perlunya konservasi lingkungan di tengah-tengah krisis ekologi global yang semakin gawat.

Prinsip mashlahah dan al-maqâshid al-syar'iyyah yang berintikan upaya pencapaian 'kebaikan atau kemanfaatan'13 dan 'tujuan-tujuan hukum' memang menjadi prinsip yang amat relevan dalam seluruh pembicaraan Syari'ah tentang konservasi lingkungan yang digunakan para ecothinkers Muslim dewasa ini. Meski teori ini muncul secara akademis pada sekitar abad-abad IV dan V H, namun argumen prinsipalnya masih relevan dengan isu-isu lingkungan meskipun, di sisi lain, argumenargumen instrumentalnya perlu penyesuaian-penyesuaian baru. Misalnya, urutan konsep al-dharûriyyât al-khams yang menyebut pemeliharaan agama di tempat pertama, disusul jiwa, keturunan, properti, dan akal. Urutan semacam ini, misalnya, dipertanyakan oleh Ibn Ashûr, ${ }^{14}$ Musthafa Abu-Sway ${ }^{15}$ dan Ali Yafie. ${ }^{16}$ Ibn Ashûr, misalnya, menambahkan dua komponen lain pada al-dharûriyyât al-khams, yakni: keadilan (al-'adâlah) dan kebebasan (al-hhurriyah). ${ }^{17}$ Musthafa Abu-Sway menyebuhkan teori al-dharûriyyât al-khams sebagai bagian organik dari pemeliharaan lingkungan. Sementara, Ali Yafie menempatkan urutan hifdh al-nafs di urutan pertama, disusul akal, properti, keturunan, dan agama. ${ }^{18}$ Modifikasi dan pengayaan teori al-dharûriyyât

12 Di antaranya adalah Ali Yafie, Merintis Fikih Lingkungan Hidup (Jakarta: Ufuk Press, 2006).

13 Makna mashlahah secara harfiah dapat dilihat dalam Ibn al-Manzkr, Lisn al-'Arab (Beirut: Dr al-Fikr, 1972), juz II, hal. 348. Secara luas definisi mashlahah di antaranya dikemukakan oleh alSyawknî mengutip al-Khawrizmi, yakni: والمر اد با لمصلحة المحافظةعلي مقصود الثنرع بدفع المفاسد عن الخلق "Maslahah adalah memelihara tujuan syari'ah dengan menghindarkan kerusakan makhluk). Lihat al-Syawknî, Irsyd al-Fuhkl il Tahqîq al-Haqq min 'Ilm al-Ushkl (Beirut: Dral-Fikr, t.thal.), hal. 242.

14 Dikutip dalam Ismail Hasani, Nazhariyyt al-Maqshid ind al-Imm Munammad al-Thhir Ibn Ashkr (Dr al-Surkq: t. p., 1991), hal. 16

15 Musthafa Abu-Sway, Towards an Islamic Jurisprudence of the Environment: Fiqh al-Bîah fî al-Isl/[m dalam http://homepage.iol.ie/ afifi/Articles/environment.htm

16 Ali Yafie, Merintis Fikih Lingkungan Hidup (Jakarta: Penerbit Ufuk, 2006).

17 Ismail Hasani, Nazhariyyt al-Maqshid..., hal. 16

18 Ali Yafie, Merintis Fikih Lingkungan Hidup..., hal. 163. 
al-khams, tentu saja, sebuah keniscayaan sesuai dengan illat hukum atau rasio legis yang berkembang secara dinamis.

Kembali pada bahasan teori al-maqâshid al-syar'iyyah, menurut al-Syâthibî, almaqâshid al-syar'iyyah atau tujuan-tujuan Syari'ah, pada dasarnya adalah untuk mencapai kemaslahatan yang terkumpul di dalam apa yang disebut al-kulliyyât alkhams atau al-dharûriyyât al-khams (yakni: memelihara agama, jiwa, keturunan, properti, dan akal). ${ }^{19}$ Menurutnya, al-dharûriyyât al-khams adalah hal-hal yang pemeliharaannya mutlak karena ia memengaruhi kemaslahatan agama dan dunia dan tanpanya kemaslahatan agama dan dunia menjadi hilang dan tidak bisa tegak secara permanen. ${ }^{20}$ Bukan hanya itu, bahkan al-Syâthibî mengatakan al-dharûriyyât al-khams sebagai prinsip universal yang diakui semua agama dengan menyebutnya “innahâ murầât fî kulli millat” (Ia merupakan aspek-aspek yang dijaga dalam ajaran semua agama). ${ }^{21}$ Dengan demikian, al-maqâshid al-syar’iyyah dioperasikan untuk mencapai kemaslahatan.

Secara etimologis, kata mashla $\underline{h} a t$ adalah kata benda infinitif dari akar kata

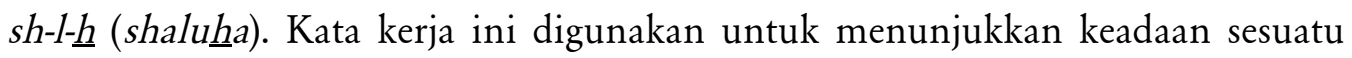
atau seseorang yang baik, sehat, benar, adil, bajik, jujur atau secara alternatif untuk menunjukkan keadaan memiliki nilai-nilai tersebut. Kata ini juga digunakan untuk sesuatu urusan atau bisnis yang kondusif terhadap kebaikan atau yang ditujukan untuk kebaikan.

Arti etimologis lain yang dikemukakan ulama ushûl tentang mashlahat adalah identik dengan kata manfaat, baik dari segi lafal maupun makna. Ia juga berarti manfaat suatu pekerjaan yang mengandung manfaat seperti dalam perdagangan. Tetapi sebenarnya ada beberapa definisi yang dikemukakan ulama ushûl yang seluruhnya mengandung esensi yang sama. Imam Al-Ghazali meringkaskan definisi mashlahat dengan mengatakan bahwa pada prinsipnya ia berarti "mengambil manfaat dan menolak kemudharatan dalam rangka merawat tujuan-tujuan syara"”22 Dalam ungkapan yang lebih jelas dalam Kitabnya, al-Mustashfâ, al-Ghazali mendefinisikan mashlahat sebagai berikut:

19 al-Sythibî, al-Muwfaqt fî Ushkl al-Ahkm, Jilid II, hal. 5

20 Dalam kalimat al-Sythibî dikatakan demikian,

الدين و الثنيا بحيث اذا فقت لم تجر مصا لح الدئا على استقا مة بل فساد وتهارج وفوت حياة انها لابد منها فى قيام مصا لح lihat lebih lanjut al-Sythibî, al-Muwfaqt, Jilid II, hal. 7

21 Periksa kembali al-Sythibî, al-Muwfaqt..., hal. 8

22 Abu Hamid Al-Ghazali, Al-Mustashf $\square$ Jilid I (Bagdad: Mutsann, 1970), hal. 286-287 


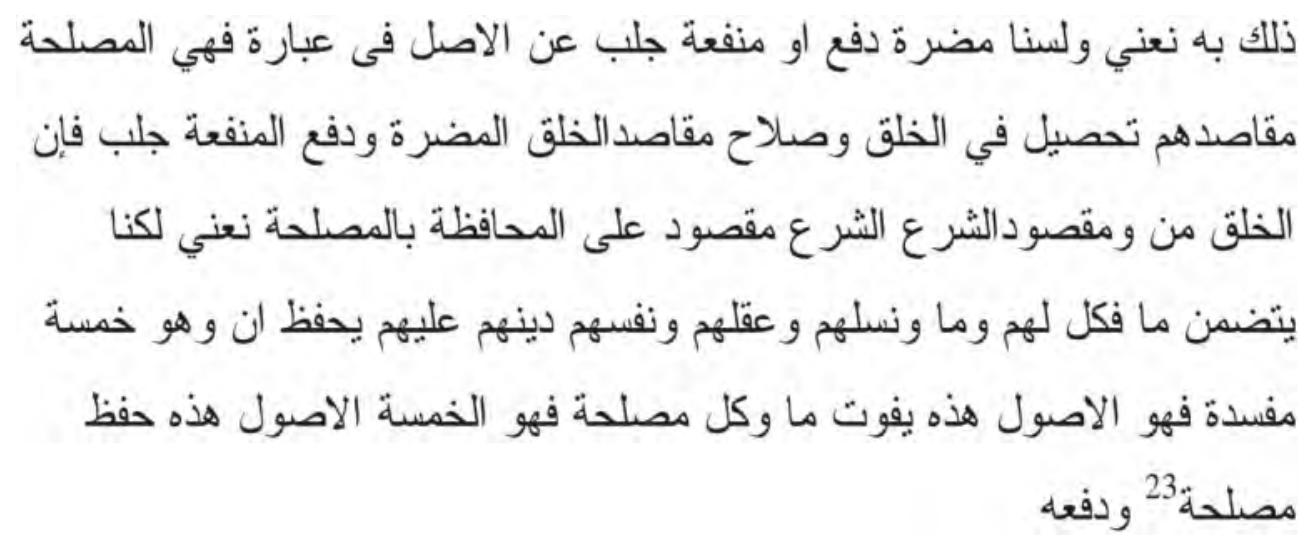

Makna asal mashlahat adalah mengambil manfaat atau mencegah keburukan. Tetapi, bukan (hanya) itu yang kami maksud. Karena mengambil manfaat dan mencegah keburukan adalah tujuan makhluk. Kemaslahatan makhluk adalah tercapainya tujuan-tujuan (kepentingan) mereka. Sebaliknya, yang kami maksud dengan mashlahat adalah menjaga tujuan Syara' dan tujuan Syara' bagi makhluk ada lima, yakni: memelihara agama mereka, jiwa, akal, keturunan, dan harta. Setiap hal (hukum/aturan) yang mengandung prinsip yang lima ini dinamakan mashlahat dan setiap hal yang menghalanginya disebut mafsadat serta mencegahnya berarti mashlahat.

Dari definisi Al-Ghazali tersebut di atas, mashlahat terkait erat dengan almaqâshid al-syar'iyyah. Kebaikan atau nilai-nilai yang mengandung kebajikan (mashlahat) harus merujuk pada terpeliharanya lima hal tadi (menjaga agama, kehidupan, akal, keturunan, dan harta benda) dan menghindarkan dari hal-hal yang mengancam atau membahayakan mereka. Karena itu, mashlahat pada dasarnya adalah tujuan yang hendak dicapai oleh al-maqâshid al-syar’iyyah. Definisi al-Ghazali (w. $505 \mathrm{H} / 1111 \mathrm{M}$ ) tentang mashlahat di atas menjadi petunjuk bahwa beliaulah yang secara teoritik merumuskan konsep al-maqâshid al-syar'yyah yang kemudian secara luas dan mendalam dikembangkan al-Syâthibî (w. 790 H/1388 M).

Adalah al-Syâthibî dari kalangan ulama klasik pasca-Ghazali yang dianggap paling concern dengan teori al-maqâshid al-syar'iyyah sebagaimana diulas dalam karyanya al-Muwâfaqât fî Ushûl al-Syarîah. ${ }^{24}$ Dalam banyak kajiannya, konsep

23 Abu Hamid al-Ghazali, al-Mustashf, Jilid I, hal. 286-287. Lihat pula Rghib al-Ishfahn, Al-Mufradtf Ghrib al-Qur'n (Karachi: Tijrat al-Kutub, 1961), hal. 286

${ }^{24}$ Secara ringkas teori Syatibi dapat dinyatakan demikian: Aturan-aturan partikular (juz’̊) Syari'ah dibangun oleh hukum-hukum universal (qawnîn kulliyah). Hukum-hukum itu diketahui melalui survai komprehensif terhadap pernyataan-pernyataan Syari'ahal. Dengan menggunakan 
mashlahat sering dipakai secara bergantian dengan al-maqâshid al-syar'iyyah dengan arti yang lebih kurang sama. Jika mashlahat adalah konsep kebaikan yang diakui secara umum, maka al-maqâshid al-syar'iyyah adalah instrumen yang menopang dan mengoperasikan konsep mashlahat itu.

Makna mashlahat dalam tradisi karya ulama klasik masih relevan. Dalam konteks konservasi lingkungan, prinsip kerja mashlahat dioperasikan untuk mencegah terjadinya kerusakan lingkungan yang dimanifestasikan dalam penjagaan atas lima hal: yakni menjaga agama, jiwa, akal, keturunan, dan properti. Lima hal ini dilihat dari perspektif ekologi adalah komponen-komponen lingkungan yang keberadaannya mutlak atau dalam terma ushûl al-fiqh disebut sebagai al-kulliyyât al-khams atau al-dharûriyyât al-khams.

Yusuf Qaradhawi mengelaborasi prinsip ini dengan menyatakan bahwa menjaga lingkungan sama dengan menjaga agama. Merusak lingkungan dan abai terhadap konservasi lingkungan sama dengan menodai kesucian agama serta meniadakan tujuantujuan Syari'ah..$^{25}$ Dengan kata lain, berbuat dosa (seperti mencemari lingkungan, merusak hutan, dan apatis pada lingkungan) dapat dianggap sebagai penodaan atas sikap beragama yang benar. Meskipun secara spesifik tidak terdapat di dalam ayat alQur'an atau Hadits yang menunjuk kata mencemari, merusak hutan, industrialisasi, dan lain-lain, tetapi jika semua itu merusak kemaslahatan maka hal itu dilarang. Penjelasannya dapat diberikan oleh konsep al-maqâshid al-syar'iyyah, yakni terkendalanya pencapaian mashlahat yang berarti merusak al-dharûriyyât al-khams.

Di bagian lainnya, Qaradhawi menyebut bahwa menjaga lingkungan sama dengan menjaga jiwa, menjaga akal, menjaga keturunan, dan menjaga properti. Rasionalitasnya adalah bahwa jika aspek-aspek jiwa, keturunan, akal, dan properti rusak, maka eksistensi manusia di dalam lingkungan menjadi ternoda. Qaradhawi mengaitkan prinsip mahslahat dalam konteks ihhsân, ibadah, dan akhlaq. ${ }^{26}$ Yusuf Qaradhawi, nampaknya,

prosedur induksi sempurna (istiqri tamm), seseorang dapat bergerak dari aturan-aturan partikular kepada hukum-hukum universal Syari'ahal. Tawaran al-Syatibi tidak lain dari suatu pergeseran yang luar biasa dalam prosedur metodologis. Karena itu, dengan menggunakan tawaran Syatibi segera akan memperluas jangkauan ijtihad dari keterbatasan-keterbatasan qiys partikular sebelumnya, kepada suatu proses komprehensif, di mana induksi dan deduksi digunakan sekaligus. Induksi memungkinkan kita bergerak dari partikular kepada general, sebaliknya deduksi bergerak dari general kepada partikular. Lihat Ibrahim ibn Musa al-Sythibî, al-Muwfaqt fî Ushk \ al-Syarî̉ah (Beirut: Dr al-Ma'rifah, t.t.), vol. 2, hlm. 29-39

25 Yusuf Qaradhawi, Islam Agama Ramah Lingkungan..., hal. 64.

26 Keseluruhan pembahasan Yusuf Qardhawi dalam bukunya ini adalah tentang pemeliharaan lingkungan dari perspektif Ushuluddin, Fikih, Ushul Fikih, Sunnah, dan Etika atau Akhlaq. Lihat Yusuf Qaradhawi, Islam Agama Ramah Lingkungan, hal. 20, 26, 51, 59, dan 74. 
mengembangkan konsep al-maqâshid al-syar'iyyah dari al-Syâthibî yang menyatakan bahwa pemeliharaan atas 'al-dharûrât al-khamsah' adalah sebuah kemutlakan yang total yang meliputi pemeliharaan atas keberadaannya dan pemeliharaan atas kepunahannya. ${ }^{27}$ Meski konsep ini dikemukakan dalam konteks abad ke-14 Masehi (masa hidup al-Syâthibî), namun prinsip-prinsip perennial-nya dapat digunakan dengan modifikasi-modifikasi baru dalam upaya Islam melakukan konservasi lingkungan.

Di masa-masa belakangan, elaborasi-elaborasi mashlahat terus mengalami dinamika dan berkesinambungan. Musthafa Abu-Sway, misalnya, juga menggunakan konsep maslahat sebagai titik tilik memproteksi lingkungan. Dia memakai konsep ini dalam bingkai al-maqâshid al-syar'iyyah (tujuan-tujuan hukum). Bahkan ia berpendapat bahwa memelihara lingkungan adalah tujuan tertinggi Syari'ah. ${ }^{28}$ Selanjutnya, menurut Musthafa Abu-Sway, dengan melihat lima komponen dasar lingkungan itu, maka disadari bahwa melindungi lingkungan hidup merupakan tujuan tertinggi Syari'ah. ${ }^{29}$ Pendapat semacam ini, tentu saja, sangat tegas dan belum pernah disampaikan oleh ulama sebelumnya, apalagi ulama klasik. ${ }^{30}$

Berbeda dengan Yusuf Qaradhawi yang nampak hati-hati, Musthafa AbuSway secara tegas memanifestasikan spirit awal al-maqâshid al-syar'iyyah yang dikemukakan al-Syâthibî di abad ke-14 $\mathrm{M}^{31}$ ke dalam spirit modern tentang keharusan mutlak memelihara lingkungan. Abu-Sway tidak saja menegaskan memelihara lingkungan itu perlu atau wajib hukumnya, tetapi justru mengatakannya sebagai tujuan tertinggi Syari’ah. Penegasan ini memiliki konsekuensi besar baik secara etis, legal, teologis, maupun filosofis. Penegasan ini dapat disetarakan dengan sebuah kemutlakan total yang bila tidak dilakukan seluruh makna kehidupan dan kekhalifahan manusia di muka bumi menjadi hilang.

27 al-Sythibî membagi mashlahat pada tiga dharkrî, hjî, dan tahsînî. Pada keharusan menjaga yang dharuri, Syatibi menyatakan bahwa jika kelima hal tidak terjaga atau rusak, maka stabilitas agama dan kehidupan menjadi rusak. Lihat al-Sythibî, al-Muwfaqt..., jilid II, hal. 8.

28 Musthafa Abu-Sway, Towards an Islamic Jurisprudence of the Environment, hal. 34

29 "...Looking at the original five, we would recognize that to protect the environment is a major aim. For if the situation of the environment keeps deteriorating, there will ultimately be no life, no property, and no religion. The environment encompasses the other aims of the Syari'ahal." Lihat Musthafa Abu-Sway, Towards an Islamic Jurisprudence of the Environment..., hal. 34.

30 Tentu saja bukan berarti ulama salaf tidak mengerti tentang masalah lingkungan, tetapi semata-mata pengetahuan tentang krisis lingkungan merupakan sesuatu yang baru. Kesadaran untuk mengatasinya pun secara global baru muncul sekitar dekade 1960-an. Lihat Mary Evelyn Tucker \& John A. Grim, Worldviews and Ecology: Religion, Philosophy, and the Environment (New York: Orbis Book, 1994). 
Musthafa Abu-Sway misalnya mengungkapkan, ".... The destruction of the environment prevents the human being from fulfilling the concept of vicegerency on earth. Indeed, the very existence of humanity is at stake here." (Kerusakan lingkungan mencegah manusia untuk memenuhi konsep wakil Tuhan di muka bumi. Sungguh, eksistensi manusia yang paling penting sedang dipertaruhkan). ${ }^{32}$ Argumen ini mempertegas prinsip al-al-maqâshid al-syar'iyyah dalam kontribusinya terhadap upaya global menanggulangi krisis lingkungan.

Selain itu, prinsip al-maqâshid al-syar'iyyah sebagai instrumen analisis fikih dapat diperkaya lagi ke unsur-unsur terkecil wacana fikih lainnya, misalnya, dalam definisidefinisi baru tentang halal dan haram (legal-formal). Pengertian halal, dalam konteks tafsiran ekologis misalnya, bukan saja harus memenuhi kriteria baik, tidak najis, atau tidak mendatangkan keburukan, tetapi juga harus memenuhi kriteria ramah lingkungan. Label halal, karena itu, harus memasukkan muatan ramah lingkungan yang dalam konsep environmentalism dikenal dengan istilah ecolabelling. ${ }^{33}$ Ecolebelling ini bukan saja berlaku dalam produk-produk makanan atau barang komoditas, tetapi juga produkproduk jasa. Demikian pula di bidang ekonomi Islam, terutama dalam masalah produksi dan konsumsi harus dikembangkan ke arah ramah lingkungan. Ke dalam kategori ini adalah ecolebelling dalam produksi hutan, teknologi transportasi, dan lain sebagainya.

Selanjutnya, di bidang kependudukan konsep al-maqâshid al-syar'iyyah dan mashlahat dapat menjelaskan secara argumentatif keharusan mengontrol kelahiran. Seperti diketahui, masalah krisis lingkungan terkait dengan masalah kependudukan. Jumlah penduduk yang tidak terkendali dapat memengaruhi daya dukung bumi dan dapat menimbulkan krisis lingkungan karena terkait dengan kesediaan logistik pangan dan kebutuhan-kebutuhan hidup layak lainnya. ${ }^{34}$ Teks-teks yang

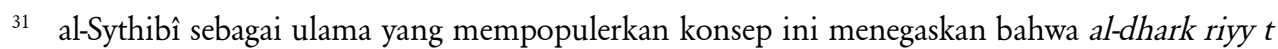
al-khams adalah wajib dan mutlak keberadaannya. Sebab tanpa kelima hal itu (memelihara agama, jiwa, akal, keturunan, dan properti) kehidupan tak pernah ada. Lihat al-Syatibi, al-Muwfaqt, jilid II, hal. 8.

32 Musthafa Abu-Sway, Towards an Islamic Jurisprudence of the Environment, hal. 34.

33 Istilah ecolabelling muncul sebagai cara baru dunia industri melindungi lingkungan. Ecolebelling diartikan sebagai "a label which identifies overall environmental preference of a product or service within a specific product/service category based on life cycle considerations." (suatu label yang mengidentifikasi keseluruhan preferensi lingkungan dari produk atau jasa dalam suatu kategori jasa atau produk khusus yang didasarkan pada pertimbangan-pertimbangan lingkungan hidup). Lihat http://www.gen.gr.jp/eco.html, diakses pada 20 April 2009.

34 Penjelasan-penjelasan tentang prediksi pertumbuhan pendudukan dan pengaruhnya pada masalah lingkungan dapat dibaca pada Joel E. Cohen, "Population Growth and Earth's Human Carrying Capacity" dalam Science 269 (21 Juli 1995): 341-346; "How Many People Can the Earth Support?”, Science 35, no 6 (November-Desember 1995), hal. 18-23. Informasi-informasi tentang prediksi pertambahan penduduk dunia juga dapat diakses pada http://www.undp.org/popin/wdtrends/ exescum.html 
'menganjurkan agar umat memiliki banyak anak' harus ditafsirkan ulang atau ditakhshîsh oleh kepentingan yang lebih tinggi yakni: terpeliharannya al-dharûriyyât al-khams dalam suatu konteks lingkungan yang sehat. ${ }^{35}$ Tegasnya, kategori-kategori dan pertimbangan-pertimbangan halal-haram, etis-tidak etis, benar-salah, dan baikburuk harus pula mencakup bobot-bobot dan pertimbangan-pertimbangan ekologis dalam pengertian holistik.

Jadi, konservasi lingkungan sebagai tujuan tertinggi Syari'ah mengharuskan sebuah perubahan mendasar orientasi fikih, teologi, dan doktrin-doktrin Islam ke arah yang lebih ekologis. ${ }^{36}$ Konsep al-Ghazali, al-Syâthibî, dan al-Syawkânî tentang mashlahat yang hanya dibatasi dalam pengertian Syara' harus diperluas ke pengertian mashlahat dalam perspektif-perspektif akal sehat. ${ }^{37} \mathrm{Hal}$ ini demikian, karena teksteks Syari'ah itu terbatas sementara perubahan-perubahan sosio-budaya dan hukum terus berkembang dengan tingkat percepatan yang sulit diprediksi. Masalah-masalah lingkungan dengan segenap turunannya (di antaranya: masalah ledakan penduduk, pencemaran, sistem ekonomi kapital, teknologi yang tidak ramah lingkungan, dan lain sebagainya) adalah masalah-masalah yang memerlukan perhatian Syari’ah. Hal inilah yang disebut sebagai krisis lingkungan dan secara ilmiah telah terbukti sebagai akibat antropogenik (disebabkan oleh aktivitas manusia yang tidak ramah terhadap lingkungan). ${ }^{38}$ Karena itu, cakupan mashlahat harus diperluas dan medan

35 Mengikuti argumentasi al-Sythibî yang ditegaskan lagi oleh Musthafa Abu-Sway bahwa memelihara الضروريات الخمس adalah sebuah kemutlakan yang total karena tanpanya aspek-aspek lain menjadi tidak berarti. Lihat al-Sytibî, al-Muwfaqt, jilid II, hal. 8. Lihat juga Musthafa AbuSway, Towards an Islamic Jurisprudence of Environment, hal. 34

${ }_{36}$ Muna Abu Fadl, misalnya, mengakui bahwa untuk memberi kontribusi dalam perumusan suatu teori sosial yang secara intrinsik bersifat Islami, ilmuwan-ilmuwan sosial Muslim harus memiliki akses terhadap sumber-sumber wahyu. Dia juga menegaskan bahwa warisan ushkl sebagaimana adanya sekarang tidak lagi memadai dan tak dapat digunakan untuk tujuan penelitian sosial. Agar operatif, metode-metode ushk $\backslash$ memerlukan suatu restrukturisasi komprehensif dengan mengelompokkan partikular ke dalam universal. Itulah sebabnya, kata Muna selanjutnya, ilmuwan-ilmuwan Muslim kontemporer tidak memiliki jalan lain kecuali membangun disiplin-disiplin mereka berdasarkan konsep-konsep yang didasarkan secara langsung dari al-Qur'an. Lihat Muna Abu al-Fadl, Towards a Methodology for Dealing with the Sources of Islamic Theorizing, Editor al-Thayyib Abidin (Herndon, VA: Institute of International Islamic Thought, 1411/1990), hal. 2072-2078.

37 Seperti diketahui mashlahat dalam teori awalnya hanya dibatasi pada hal-hal yang telah disebut baik atau manfaat oleh Syari'ahal. Teori ini kemudian dikritik di antaranya oleh para teologi seperti 'Asy'arî. Menurut teologi ini, kemaslahatan tak dapat diketahui tanpa melalui proses penalaran akal. Bandingkan dengan Muhammad Khalid Masud, Islamic Legal Philosophy: A Study of Abu Ishaq al-Syathibi's Life and Thoght (Islamabad: Islamic Research Institute, 1977).

38 Tentang Krisis lingkungan sebagai akibat dari aktivitas manusia yang ceroboh (antropogenik) dapat dibaca di antaranya dalam D. Meadows et. al., The Limits to Growth (New York: Potomac Associate, 1972). 
pengertiannya juga harus mencakup ayat-ayat Allah yang bersifat fi'liyyah, yakni alam semesta (ayat kawniyyah). ${ }^{39}$

Najmuddîn al-Thûfî dalam konteks perluasan makna mashlahat dapat dianggap sebagai dukungan klasik atas argumen di atas. ${ }^{40}$ Menurutnya, mashlahat dapat didasarkan pada empat prinsip, yakni: pertama, akal bebas menentukan mashlahat dan mafsadat, terutama dalam lapangan muamalah dan adat. Untuk menentukan suatu mashlahat dan mafsadat cukup dengan akal. Pendiriannya bahwa akal semata tanpa harus melalui wahyu mampu mengetahui kebaikan dan keburukan ( $\underline{h} u s n$ dan $q u b \underline{h}$ ) menjadi landasan yang pertama dalam piramida pemikirannya. Tetapi dia membatasi kemandirian akal itu dalam bidang muamalah dan adat-istiadat, dan melepaskan ketergantungan atas petunjuk nashsh. Kedua, mashlahat merupakan dalil syar'î mandiri yang kehujahannya tidak tergantung pada konfirmasi nashsh, tetapi hanya tergantung pada akal semata. Dengan demikian, mashlahat merupakan dalil mandiri untuk menetapkan hukum karena, baginya, sesuatu itu bermanfaat atau mengandung mashlahat bisa dinalar dengan atau melalui adat-istiadat dan eksperimen tanpa petunjuk nashsh.

Ketiga, mashlahat hanya berlaku dalam lapangan muamalah dan adat kebiasaan. Sedangkan dalam bidang ibadah ukuran-ukurannya ditentukan oleh syara'seperti pada ibadah mahdhah (salat lima waktu, puasa bulan ramadhan, dan lain sebagainya). Hal ini demikian karena hal tersebut merupakan huqûqullâh (hak-hak Allah). Selanjutnya, dia juga mengatakan bahwa pada hubungan antar manusia itulah akal sangat mengetahui baik dan buruknya. Keempat, mashlahat merupakan dalil syara'yang paling kuat. Karena itu, jika ada nashsh dan ijma' bertentangan dengannya (mashlahat), ia harus didahulukan dari keduanya dengan cara takhshîsh dan bayân terhadap nashsh. Jadi bukan dengan meninggalkan nashsh sama sekali. ${ }^{41}$ Pandangan al-Thûfî di atas, sungguh, telah malampaui pandangan pendahulunya dan merefleksikan gerak maju ushûl al-fiqh dalam mengakomodir perkembanganperbangan baru sosio-budaya. ${ }^{42}$

39 Tentang kosmos sebagai ayat-ayat Allah dibahas secara detail pada bab IV.

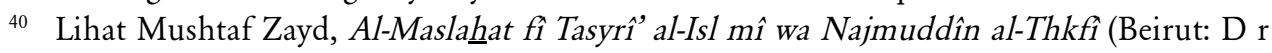
al-Fikr, 1954), h . 127-132

41 Lihat Mushtaf $\square Z$ Zayd, Al-Maslahhat fî Tasyrî̀ al-IsImî wa Najmuddîn al-Thkfî, h . 127-132. Lihat juga Husein Hamid Hasan, Nadzariyyt al-Mashlahah fî al-Fiqh al-Isl[mî (Qhirah: D马 alNahdhah al-'Arabiyyah, 1971), hal. 529.

42 Bandingkan Bassam Tibi, Islam and the Cultural Accommodation of Social Change (San Fransisco \& Oxford: Westview Press, 1990). 
Dengan demikian, tujuan Syari'ah untuk kemaslahatan manusia sebagaimana banyak dikemukakan oleh para ulama klasik sudah tidak memadai lagi. Tujuan Syari'ah, dalam konteks ini, ditujukan untuk kemaslahatan lingkungan semesta yang pada akhirnya menjadi kemaslahatan manusia juga. Analisis ini didasarkan pada pertama, adanya kenyataan bahwa terpeliharanya al-dharûriyyât al-khams, pada dasarnya, tak akan tercapai tanpa lingkungan hidup yang baik yang menjadi prasyarat kehidupan. Kedua, manusia itu datang dan pergi dari jaman ke jaman, sementara lingkungan hidup terus ada dan bahkan menjadi satu-satunya, yakni: planet bumi. ${ }^{43}$ Karena itu, jika konsep Syari'ah dirumuskan secara antroposentris maka memberi persetujuan teologis kepada manusia untuk melakukan agresi terhadap lingkungan hidup tanpa memikirkan visi keberlanjutan bagi generasi manusia selanjutnya di masa-masa mendatang. Ketiga, lingkungan alam adalah amânah dan bukan aset. Karena itu, lingkungan alam bukan milik manusia tetapi hanya dimanfaatkan secara baik serta dirawat dengan penuh tanggung jawab. Itulah sebabnya, manusia disebut sebagai khalîfatullâh fî al-'ardh. Dalam pengertian inilah, konsep Islam atau Syari’ah harus berbeda dengan pandangan kaum reduksionisme seperti yang dengan terangterangan dikemukakan oleh Francis Bacon dengan ungkapannya, "Tujuan ilmu adalah penguasaan dan pengendalian alam. Ilmu pengetahuan dapat digunakan untuk mengubah manusia menjadi tuan dan pemilik alam”. ${ }^{44}$

Dengan menggunakan prinsip-prinsip al-maqâshid al-syar'iyyah dan mashlahat di atas, konsep khalîfatullâh fî al-ardh, taskhîr ${ }^{45}$ dan i'mâr ${ }^{46}$ yang terlalu menempatkan manusia sebagai “penguasa alam” oleh para mufassir klasik dan modern perlu direvitalisasi ke dalam konsep holistik tentang konservasi lingkungan dalam tatapan-tatapan yang lebih ekologis. Kealpaan fikih-fikih klasik dalam mengurai masalah konservasi lingkungan secara spesifik bukanlah alasan untuk menunda kontribusi Islam atas krisis lingkungan. Alat-alat bantu analisis telah disuplai oleh disiplin-disiplin lain, seperti metafisika sains dari Seyyed Hossein Nasr, Ziauddin Sardar, Nomanul Haqq, dan lain-lainnya. Dari disiplin ekologi dan ilmu perubahan iklim, konsep-konsep konservasi lingkungan

43 Sejarah bumi menunjukkan bahwa planet bumi dapat hidup selama milyaran tahun tanpa manusia sampai akhirnya makhluk manusia datang ke bumi dan melakukan eksploitasi terhadap alam. Itulah sebabnya, perintah manusia sebagai khalifatullth fî al-'ardh sangat relevan dalam konteks pemeliharan atas bumi. Lihat QS, al-Baqarah/2: 30

44 Dikutip kembali dalam Fritjof Capra, Titik Balik Peradaban..., hal. 53

45 QS, al-Jtsiyah/45: 13 
juga telah memperoleh bahan-bahan berarti sehingga ini semua dapat menjadi ingredients dalam merumuskan konsep-konsep utama melindungi lingkungan dari sisi Islam, utamanya dalam perspektif al-maqâshid al-syar'iyyah dan mashlahat.

Lebih lanjut, 'Izz al-Dîn bin 'Abd al-Salâm mengeloborasi bahwa mashlahat itu ada empat macam: kelezatan (al-ladzât) dan faktor-faktor penyebabnya, kesenangan (al-afrâh $\underline{\text { }}$ ) dan sebab-sebabnya. Sementara mafsadat juga ada empat, yakni: rasa sakit/tidak nyaman dan faktor penyebabnya, serta rasa sedih dan faktor penyebabnya. ${ }^{47}$ Perluasan makna mashlahat dan mafsadat ini mengandung perluasan kapasitas teori tersebut untuk mengakomodir dinamika problem hukum dan moral masyarakat manusia. ${ }^{48}$

Mengikuti garis argumen 'Izz al-Dîn bin 'Abd al-Salâm di atas, konsep mashlahhat dan lawannya mafsadat di dalam tradisi fikih, teologi, dan etika Islam memunculkan konsep ishlâh, yang secara harfiah berarti 'konservasi' ${ }^{49}$ dan lawannya adalah ifsâd (dari kata fasad), yang berarti destruksi atau tindakan merusak (corruption). ${ }^{50}$ Kata ishlâh di dalam al-Qur'an dihubungkan dengan kata ifsâd yang keduanya dipakai dalam konteks bumi. Lengkapnya terjemah ayat itu adalah, "Janganlah kalian membuat kerusakan di muka bumi, sesudah mengkonservasinya." ${ }^{51}$ Kata ishlâh dengan kata turunannya diulang di dalam al-Qur'an sebanyak 181 kali. ${ }^{52}$ Ini menunjukkan pentingnya makna ini dalam konteks perlindungan lingkungan dan aspek-aspek yang terkait dengannya sehingga menimbulkan kebajikan-kebajikan otentik sebagaimana makna harfiah kata itu. ${ }^{53}$

46 QS, Hkळ/11: 61

47 'Izz al-Dîn bin 'Abd al-Sal[m, Qaw'id al-Ahkkm..., hal. 11-12

48 Teori ini dalam tradisi ushkl al-fiqhal. Teori ini adalah pengembangan dari mashlahat, dan pemakaiannya secara hukum masih diperdebatkan di kalangan para yuris klasik. Hal ini demikian, karena al-mashlahat al-mursalah merupakan kebaikan dan kemanfaatan yang tidak disebutkan keharamannya ataupun kehalalannya. Lihat lebih lanjut Zakîy al-Dîn Sya'bn, Uhkl alFiqh al-IsImî (t.k.: Dr al-Nahdhah al-'Arabiyyah, t.th), hal. 182 dan Wahbah Zuhaylî, Ushkl al-Fiqh al-IsImî (Beirut: Dr al-Fikr al-Mu’shir, 1986), cet. ke-I, hal. 757

49 Saya pilih memaknai kata ishlh dengan makna 'konservasi' agar relevan dengan konteks bahasan ekologi. Apalagi kata itu terkait dengan larangan merusak bumi.

50 Kata ishlh berasala dari akar kata shad, lam, ha yang berarti layak, bagus, dan lawannya adalah fasad, yang berarti jelek atau rusak. Lihat Abu al-Hasan Ibn Faris bin Zakariya, Mu'jam Maqyîs al-Lughah, hal. 303.

51 Q. s., al-A'rf/7:56

52 Lihat Muhmmad Fu'ad Abdul Bqi, al-Mu'jam al-Mufahras lil-Alfdz al-Qur'n al-Karîm (Maktabah Dahlan, Indonesia, t.thal.), hal. 520-523

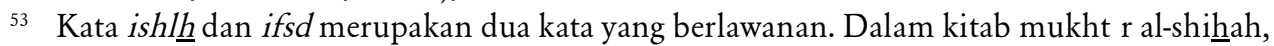
misalnya, dua kata itu didefinisikan demikian: الصلا ح ضد الفسا د و المصلحة واحدة المصالح و الا سنصلاح ضد الا ستفسا د. Lihat al-Rzî, Mukht_t al-Shihah (Beirut: t. tp., 1952), hal. 75. 
Kata ifsâd sebaliknya menunjukkan suatu tindakan merusak (afsada, yufsidu, ifsâd) yang dalam ayat di atas terkait dengan larangan merusak bumi. Jika kata ini dikaitkan dengan Q. s., al-Rûm/30:41 yang menjelaskan kerusakan di daratan dan lautan akibat ulah tangan-tangan manusia, maka konsep ifsâd adalah sebuah antitesis dari konsep konservasi lingkungan atau ishlâh al-bî̀ah (ri'âyat al-bî̀ah).

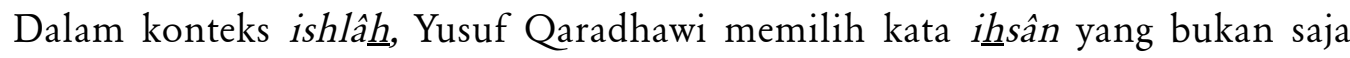
dikaitkan dengan ibadah, tetapi juga dikaitkan dengan berbuat baik kepada atau untuk merawat, menghormati, dan lemah lembut terhadap lingkungan. ${ }^{54}$ Prinsipprinsip konservasi lingkungan dalam titik tilik eko-ushûl al-fiqh di atas menunjukkan sebuah etos otentik yang semuanya bertujuan pada kebaikankebaikan lingkungan dengan seluruh komponennya. Prinsip-prinsip itu pada dasarnya mengerucut pada pentingnya proteksi lingkungan sebagai sangat utama dan pertama karena lingkungan yang makin buruk membuat pemeliharaan atas agama, jiwa, akal, keturunan, dan properti menjadi tidak ada (الضروريات الخمس). Prinsip inilah yang dalam tradisi ushûl al-fiqh disebut sebagai al-maqâshid alsyar'iyyah (المقاصد الثرعية).

Uraian tentang ishlâh dan ifsâd di atas adalah kelanjutan operasional dari almaqâshid al-syar'iyyah, sekalipun juga menjadi bagian dari bahasan etis sebagaimana dikemukakan para mufassir dalam karya-karya mereka, terutama ketika mengomentari ayat-ayat tentang ishlâh dan ifsâd. Ayat-ayat 'lingkungan dan konsep perlindungannya' di dalam al-Qur'an dan Hadits, pada dasarnya, perlu penjelasan operasional melalui argumen-argumen fikih dan perangkat metodologinya, yakni: ushûl al-fiqh. Karena itu, perspektif al-maqâshid al-syar'iyyah dapat memperkaya basis imperasi etis konservasi lingkungan.

Terkait dengan teori al-maqâshid al-syar'iyyah dan mashlahat di atas, maka konservasi lingkungan dalam perspektif eko-ushûl al-fiqh dapat dirumuskan dengan, sedikitnya dua jalan. Pertama, melakukan redefinisi tentang dosa, hukum halalharam, baik-jelek, etis-tidak etis, dan benar-salah dengan memasukkan komponen keselamatan lingkungan. Ini berarti konsep mashlahat dan mafsadat tidak cukup hanya menyangkut kepentingan manusia saja, tetapi juga menyangkut aspek keselamatan lingkungan. Kedua, mempelajari ayat-ayat kawniyyah berupa ilmu geografi, ilmu lingkungan, ilmu fisika, dan perangkat-perangkat lain yang dapat menunjang konservasi lingkungan adalah setara nilainya dengan mempelajari ilmu

54 Bandingkan dengan Yusuf Qaradhawi, Islam Agama Ramah Lingkungan..., hal. 184-185 
agama. Hal ini demikian, karena menjaga al-dharuriyyât al-khams tidak akan terjadi tanpa sarana-sarana pendukungnya, yaitu ilmu-ilmu yang diperlukan untuk itu. Pandangan tradisional sering menekankan ilmu agama sebagai fardu 'ayn sementara mempelajari selainnya dianggap fardhu kifâyah. ${ }^{55}$ Dua rumusan tersebut merupakan salah satu cara memperlakukan konsep al-maqâshid al-syar'iyyah dan mashlahat dalam konteks konservasi lingkungan.

Jadi, dilihat dari kajian yang lebih mendalam, prinsip al-maqâshid al-syar'iyyah dan mashlahat merupakan suatu metodologi yang paling relevan dan paling bertahan dalam relevansinya dengan problem-problem kehidupan kontemporer, ${ }^{56}$ termasuk dalam problem dan krisis-krisis lingkungan beserta upaya konservasinya. Namun, penyempurnaan atas detail-detailnya perlu dilakukan sehingga berpihak pada keterpeliharaan lingkungan.

Teori al-dharûriyyât al-khams al-Syâthibî, sesungguhnya, tidak memadai untuk mendukung secara penuh konservasi lingkungan. Teori al-dharûriyyât al-khams yang mementingkan keterpeliharaan lima komponen: agama, jiwa, keturunan, harta, dan akal nampak antroposentris (berpusat pada kepentingan manusia). ${ }^{57}$ Mashlahat yang ingin dicapai dalam teori al-Syâthibî adalah kemaslahatan manusia di dunia dan di akhirat. Keselamatan manusia di dunia, menurut perspektif teori ini, adalah terpeliharanya kebutuhan-kebutuhan dasar yang melekat pada manusia itu (aldharûriyyât al-khams). Sementara keselamatan di akhirat terutama oleh terpeliharannya agama. ${ }^{58}$ Keselamatan non-manusia di anggap sebagai sekunder (pelengkap) atau hâajiyât dan tersier atau tahsîniyyât. ${ }^{59}$ Dengan yakin al-Syâthibî "mengatakan “" أن مصالح الدين و الدنيا مبنية علي المحافظة علي الامور الخمسة|لدذكورة فيماتقام

55 Dalam urutan komponen al-dharkriyyt al-khams yang disebut pertama oleh al-Ghazali dan alSythibî adalah komponen agama, disusul jiwa, keturunan, harta, dan akal. Tentu saja, ini menunjukkan bahwa memelihara agama itu paling utama, padahal dia menjadi kurang berarti jika kondisi jiwa sakit atau jika lingkungan terus dalam ancaman bencana dan terus dalam krisis yang akut.

56 Henry Laoust, misalnya, sangat memuji teori mashlahat dan al-maq \$hid al-syar'iyyah sebagai kekayaan peradaban Muslim. Ia mengatakan bahwa prinsip masòlahat dan al-maqshid al-syarî̉ah adalah salah satu gagasan yang membuat teori Hukum Islam dan studi-studi Islam lebih unggul daripada Kristen. Karena prinsip inilah Islam memiliki kesadaran akan realitas secara lebih maju daripada Kristen. Dikutip kembali dalam Muhamad Khalid Masud, Islamic Legal Philosophy: A Study of Abu Ishaq al-Syatibi's Life and Thought (Islamabad: Islamic Research Institute, 1977), hal. 98.

57 Periksa al-Sythibî, al-Muwfaqt..., hal. 8

58 Periksa contoh-contoh yang diberikan oleh al-Sythibî dalam al-Muwfaqt, hal. 8

59 Periksa al-Sythibî, al-Muwfaqt..., hal. 9 
("Sejatinya, kemaslahatan agama dan dunia dibangun atas dasar terpeliharanya lima komponen yang disebut terdahulu”). ${ }^{60}$ Meski teori al-Syâthibî, bukan satu-satunya yang menyebut kemaslahatan manusia, teori ini mendukung konsep khalîfatullâh dalam pengertian antroposentris yang menekankan makna taskhîr sebagai penundukan terhadap alam.

Dilihat dari perspektif konservasi lingkungan dalam pengertian modern seperti dikemukakan oleh Seyyed Hossein Nasr ${ }^{61}$ teori antrposentrisme tentang khalîfah sebagai al-âlam al-shaghîr (mikrokosmos) harus dimaknai ulang dan dikembalikan pada kepentingan-kepentingan yang lebih besar, yakni alam semesta sebagai al-âlam al-kabîr (makrokosmos). ${ }^{62}$ Spirit konservasi lingkungan memerlukan perangkat pemahaman yang sama sekali baru tentang hubungan antara Allah, alam, dan manusia. Teori fikih dan ushûl al-fiqh yang dibangun masih mengikuti urutan logikan Abad Pertengahan ketika manusia terancam oleh alam. Perubahan illat atau rasio legis telah berubah ketika alam justru terancam oleh manusia. Perubahan illat hukum ini mengubah pula konsep mashlahat dan al-maqâshid al-syar'iyyah yang dalam penelitian ini mendukung konsevasi lingkungan sebagai tujuan tertinggi Syari'ah.

Namun demikian, teori al-Syâthibî menyumbangkan gagasan berharga tentang konservasi lingkungan terbatas. Perluasan, pembesaran kapasitas, dan pengembangannya ke arah yang lebih ekologis telah dilakukan banyak intelektual Muslim dan non-Muslim dalam kerangka teori ekoteologi, ekosofi, ekosufi, dan etika lingkungan Islam.

Selanjutnya, melalui pintu teori dan prinsip al-maqâshid al-syarî̉ah dan mashlahat ini, revitalisasi fikih, pemahaman Syari'ah, dan pemikiran Islam dapat berkembang secara dinamis. Dalam konteks konservasi lingkungan, sebagaimana ditunjukkan Musthafa Abu-Sway dan Yusuf Qaradhawi, prinsip ini mampu mendobrak atau mendekonstruksi kebekuan fikih untuk selanjutnya merekonstruksinya menjadi sebuah fikih yang terus relevan dan up-to-date. Dalam

60 Periksa al-Sythibî, al-Muwfaqt..., hal. 13.

${ }^{61}$ Seyyed Hossein Nasr, The Encounter of Man and Nature (California: University of California Press, 1984) juga karya-karya belakangan yang memfokuskan pada pemihakan lingkungan di antaranya Richard C. Foltz (Ed.), Worldviews, Religion and the Environment: A Global Anthology (Beltmont, Calif: Wadsworth Thomson, 2002).

62 Periksa kembali konsep kosmologi Ibn 'Arabî dalam Futuht al-Makkiyyah, Edisi Usman Yahya (Cairo: al-Hay’ah al-Mishriyyah al-'mmah li al-Kuttb, 1972), Jilid III, hal. 350 
kerangka perubahan makna dan perluasan (tawassu') cakupan teori mashlahat dan al-maqâshid al-syar'iyyah tersebut konsep-konsep konservasi lingkungan dalam perspektif fikih ini dilakukan.

\section{E. Penutup}

Argumen eko-ushûl al-fiqh merupakan sebuah upaya dekonstruksi atas dimensidimensi internal Syari'ah yang belum tergali terkait konservasi lingkungan. Dalam banyak literatur tafsir, kajian tentang konservasi lingkungan hanya bersifat generik dan tidak bersifat spesifik, sehingga mencari panduan yang applicable tentu saja sukar didapat. Yang bisa diperoleh hanya pesan-pesan umum mengenai etika memperlakukan lingkungan.

Itulah sebabnya, argumen eko-ushûl al-fiqh dimaksudkan untuk mengeksplorasi segi-segi lingkungan secara lebih spesifik melalui metodologi hukum Islam. Secara umum, tulisan ini mengandaikan bahwa melakukan dekonstruksi Syari'ah untuk konservasi lingkungan tidak bisa dilakukan tanpa mendekonstruksi ushûl al-fiqh. Dekonstruksi ini dilakukan bukan untuk membongkar dan membiarkannya dalam mozaik-mozaik pemikiran tanpa makna, tetapi hendak direkonstruksi agar mampu memperbesar kapasitas kandungan Syari'ah. Dekonstruksi tanpa rekonstruksi hanya akan meninggalkan puing-puing yang lebih berbahaya.

Dalam garis argumen ini, eko ushûl al-fiqh merupakan zeit geiss (semangat jaman) di mana manusia modern tengah dihantui oleh kiamat dini melalui ancaman krisis lingkungan global oleh perilaku-perilaku anti-konservasi. Komunitas Muslim, sebagai bagian dari komunitas dunia perlu memberikan kontribusi moral dan ilmiah bagi upaya manusia sejagad mengatasi krisis lingkungan melalui eksplorasi ajaranajarannya. Tanpa kontribusi ini, maka kehadiran agama Islam akan dipertanyakan oleh sejarah dan dinilai apatis pada persoalan-persoalan aktual masyarakatnya.

\section{DAFTAR PUSTAKA}

\section{Al-Qur'an al-Karim}

Abu-Sway, Mustafa. 1998 Towards an Islamic Jurisprudence of the Environment: Fiqh al-Bî̀ah fî al-Islâm, http://homepage.iol.ie/ afifi/Articles/ environment.htm. Februari.

Abu Zahrah, Muhamad. Tanpa tahun. Ushûl al-Fiqh. Kairo: Dâr al-Fikr 'Arabi. 
Al-Bazdawi. 1966. Kanz al-Wushûl ilâ Ma'ârifl Ushûl. Karachi: t.p.

Afrasiabi, L. Kaveh. 2002. "Towards an Islamic Ecotheology", diterbitkan ulang dalam karya Richard C. Foltz (Ed.), World-views, Religion and the Environment: A Global Anthology. Beltmon, Calif: Wadsworth Thomson.

Ammara. 2009. Mohammad. The Vicegerency of Man dalam http://www.isesco.org.ma/ english/publications/Islamtoday/13/P4.php, diakses pada 23 januari.

Badran, Abu al-'Ainayn. Tanpa tahun. Ushûl al-Fiqh al-Islâmî. Iskandariyah: Mu'assasah Shabab al-Jâmi'ah.

Baharuddin, Azizan. Rediscovering the Resourcess of Religion dalam http:// www.idrc.ca/fr/ev-88052-201-1-DO_TOPIC.html

Brown, Lester R. (ed.). 1993. Jangan Biarkan Bumi Merana: Laporan Worldwatch Institute, ter. Budi Kusworo. Jakarta: Yayasan Obor Indonesia.

Campbell, Ian. 1972. "Conservastion and Natural Resouces” dalam Charles F. Park, Jr., Earth Resources. Washington DC: American Voice of America.

Cohen, Joel E. 1995. "Population Growth and Earth's Human Carrying Capacity”, dalam Science 269, 21 Juli.

Deen, Mawil Y. 2007. Izz. Islamic Environmental Ethics, Law, and Society. http:// hollys7.tripod.com/religionandecology/id5.html, diakses tanggal 28 Mei.

Ebrahim, Abul Fadl Mohsin. 1989. Abortion, Birth Control, and Surrogate Parenting: An Islamic Perspective. Indianapolis: American Trust Publications.

Foltz, Richard, Frederick Denny, and Azizan Baharuddin (Ed.). 2003. Islam and Ecology: A Bestowed Trust. Cambridge: Harvard University Press.

Gore, Al. 1992. Earth in the Balance: Ecology and the Human Spirit. Boston: Houghton Mifflin.

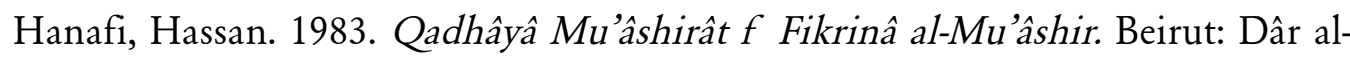
Tanwîr li al-Thibâ'at al-Nasyr, cet.-2.

Hasani, Ismail. 1991. Nazariyyat al-Maqashid inda al-Imâm Muhammad al-Thâhir Ibn 'Ashûr. Dar al-Shuruq: t.p.

Hibri, Azizah. 1993. "Family Planning and Islamic Jurisprudence” dalam Religious and Ethical Perspective on Population Issues. Washington DC.: Religious Consultation on Population. 
Ibn 'Abd al-Salâm, Izz al-Dîn. 1994. Qawâ’d al-Ahhkâm fî Mashâlihh al-Anâm. Qâhirah: Maktabah al-Kulliyyât al-Azhariyyah.

Ismail Faruqi and Lois Lamya Faruqi. 1986. The Cultural Atlas of Islam. New York: Macmillan Pub. Co.

Khalid, Fazlun M. and Joanne O’Brien, eds. 1992. Islam and Ecology. London: Cassel Publisher.

Meadows, D.et al. 1972. The Limits to Growth. New York: Potomac Associate.

Nabhan, Muhammad Faruq. Tanpa tahun. al-Madkhal li al-Tasyrî̀ al-Islâmî. Beirut: Dâr al-Qalam

Nadwi, Ali Ahmad al-. 1994. al-Qawâ’id al-Fiqhiyyah: Mafhûmuhâ, Nasyatuhâ, Tathawwuruhâ, Dirâsat Mu'allafâtihâ, Adillatuhâ, Muhimmatuhâ, Tathbîqâtuhâ. Damaskus: Dâr al-Qalam.

Nasr, Seyyed Hossein. 1987. Traditional Islam in the Modern World. London and New York: Kegan Paul International.

. 2002. The Heart of Islam: Enduring Values for Humanity. New York: HarperCollins Publisher, Inc.

1996. Religion and the Order of Nature. New York: Oxford University Press.

1984. The Encounter of Man and Nature. California: University of California Press.

1990. "Islam and the Environmental Crisis", dalam Journal of Islamic Research, vol. 4, no. 3, July.

Ozdemir, Ibrahim. An Islamic Perspective of Environmental Ethics, http:// www.nur.org/treatise/articles/IslamicEnvironmentalEthics.html. Karya ini telah bukukan dengan judul The Ethical Dimension of Human Attitude Towards Nature (Ankara: Ministry of Environment, 1997).

Qaradhawi, Yusuf. 2001. Ri'ayatul Bi’ah fi Syari'atul Islam. Qahirah: Dar al-Syuruq.

-_-_-_. 1998. al-Siyâsah al-Syar'iyyah fî Dhau' al-Nushûs al-Syari’ah wa Maqâshidihâ. Kairo: Maktabah Wahbah.

Rahman, Fazlur. 1980. Major Themes of the Qur'an. Minneapolis, Chicago: Bibliotheca Islamica. 
Richardson, John. The Spiritual Roots of Our Ecological Crisis: Was Lynn White Right dalam http://www.btinternet.com/ i.p.richardson/lynnwhite.html.

Salim, Emil. 1992. "Kesinambungan dan Pembaruan” dalam Analisis CSIS, Tahun XXI. No. 6 November-Desember.

Sardar, Ziauddin. 1985. Islamic Futures. New York: Mensell Publishing Limited. 